\title{
Institutional Transformation Plan of Directorate Generale of Taxation
}

\author{
Tio Andiko and Inayati
}

\begin{abstract}
This research is motivated by the condition where the realization of tax revenue has not reached the target in recent years, then the emergence of various recommendations from some parties regarding the need for authority flexibility in the Directorate Generale of Taxation (DGT), reinforced by the trend of transformation of the more autonomous tax authorities in the other countries. The purpose of this study is to analyze the appropriate institutional design for the DGT in order to realize a good internal control system within the Ministry of Finance. The focus of this research is the internal control system of the Ministry of Finance and the restructuring of the DGT. The conclusions drawn from this study led to the establishment of DGT with the status of Non-Ministry Government Institution, whose position is directly under and responsible to the President through the coordination of the Ministry of Finance.
\end{abstract}

Index Terms - Autonomy, Organization, Tax Administration, Semi Autonomous Revenue Authority

\section{INTRODUCTION}

Entering the year 2015, the current global economic conditions have undergone many changes. Based on the Global Economic Prospect (GEP) report released by the World Bank Group it is explained that, after growing by $2.6 \%$ in 2014 , the global economy is expected to increase by $3 \%$ this year, $3.3 \%$ in 2016 and $3.2 \%$ by 2017. Developing countries will also increase by $4.4 \%$ in 2014 and could rise to $4.8 \%$ in 2015 , then increase to $5.3 \%$ and $5.4 \%$ in 2016 and 2017[1].

The World Bank predicts that Indonesia's economic growth for 2015 will not increase significantly. It will only increase slightly from $5.1 \%$ in 2014 to $5.2 \%$. The current Indonesian government is also faced with the issue of state revenue that continues to degrade only slightly above $11 \%$ of GDP[2]. Total GDP revenue is projected to decline to $13.7 \%$ in 2019 if the government does not reform. Therefore, the future government should increase state revenues by optimizing tax revenues. This can be done by reforming the revenue policy to expand the tax base, rationalize the tax type, simplify the tax structure, and revise some tax rates to be comparable with international tariffs selectively[3].

Given the current global economic conditions and Indonesia, it is certainly a top priority for the government in optimizing tax revenue as one of the most potential sources of state revenues in sustaining national economic growth. As stated in Law no. 6 of 1983 as has been amended the latest by Law no. 16 Year 2009 on General Provisions and Procedures of Taxation, which explains that tax is a compulsory contribution to a country that is owed by an individual or a coercive body under the law, by not obtaining direct remuneration and being used for the purposes of the state to the greatest possible extent prosperity of the people.

Consecutively from year to year, tax revenues contribute enormously to state revenues. This can be seen in Table 1 on the contribution of tax revenue to state revenues. Proven for the last five consecutive years of $72.89 \%$ in $2010 ; 72.5 \%$ in 2011 ; $73.59 \%$ in $2012 ; 76.68 \%$ in $2013 ; 78.87 \%$ in 2014 and the revenue sector contributes more than other sectors.

TABLE I: Contribution Of Tax Receipts To State Revenues

\begin{tabular}{|c|c|c|c|}
\hline Year & Tax Revenue & $\begin{array}{c}\text { State } \\
\text { Revenue }\end{array}$ & Percentage \\
\hline 2013 & 1.077 .307 & 1.438 .891 & $74.87 \%$ \\
\hline 2014 & 1.146 .866 & 1.550 .491 & $73.97 \%$ \\
\hline 2015 & 1.240 .419 & 1.508 .020 & $82.25 \%$ \\
\hline 2016 & 1.539 .166 & 1.786 .225 & $86.17 \%$ \\
\hline 2017 & 1.495 .894 & 1.737 .630 & $86.09 \%$ \\
\hline \multicolumn{4}{|c|}{ Source: Data processed, 2018 } \\
\hline
\end{tabular}

This makes the realization of tax revenue from year to year as one of the most highlighted by many parties, especially the economic observers from various professions. Various opinions and recommendation views continue to roll in order to improve efforts to optimize tax revenue. To be able to function optimally, tax administrators need to have four organizational-related powers, Human Resources, budgets and information technology, as stated by Wahju K. Tumakaka. The current condition illustrates that the authority in these four aspects is not owned by the DGT. Authority in terms of additional employees, is in the Bureau of Human Resources Ministry of Finance, BKN and the Ministry of PAN-RB[4]. Chairman of BPK for the Period of 2014, Rizal Djalil also suggested that institutions that take care of tax revenue in Indonesia can stand alone and directly responsible to the president. The institution may be a separate ministry or entity or in other words the DGT should leave the Ministry of Finance[5].

One very clear condition nowadays is where the DGT as an agency that takes care of tax revenues is still one body under the Ministry of Finance. Looking at the current state, it can be said that functionally, the Ministry of Finance has a function to carry out all phases of transactions ranging from recording, execution, and storage or management. This includes the DGT that serves as a tax manager (state revenue) in the body of the Ministry of Finance. Obviously this is not in accordance with the provisions contained in the theory of internal control. 
Kaldor in Darussalam, et. al.[6] states, appropriate taxation laws alone are not enough or may not have a significant effect. The decisive thing lies precisely in how effective and efficient the tax administration in a country is. Tax administration functions to implement and enforce tax laws based on the authority granted by tax laws.

Various attempts to run the tax administration within a country are generally assigned to a tax authority granted authority by law, acting as tax administrators in charge of encouraging compliance while facilitating taxpayers against tax provisions $^{[7]}$. The success of a tax administration is greatly influenced on how optimal the performance of its tax authorities can work, in this case the DGT as the tax authority appointed by the government as the tax administrator in Indonesia.

Indonesia's current tax condition is faced with the conditions under which the DGT with its institutional design has limited authority in encouraging the realization of an effective and efficient tax administration. The proposed changes to the institutional framework of good tax administration should, at least, have the following characteristics[8]. First, it has financial independence. Secondly, the new agency / body is granted autonomous administrative authority and can formulate its policy and administrative objectives. Finally, the new agency / agency must be responsible for managing human resources internally.

In the last two decades, the model of tax authorities in the form of directorates under the Ministry of Finance has been increasingly abandoned. Many countries have turned the tax authority into a more autonomous tax authority known as the semi-autonomous tax authority. The main reasons for the emergence of such transformations stem from the need for sustained acceptance, service improvements, and improved governance in the tax sector[9].

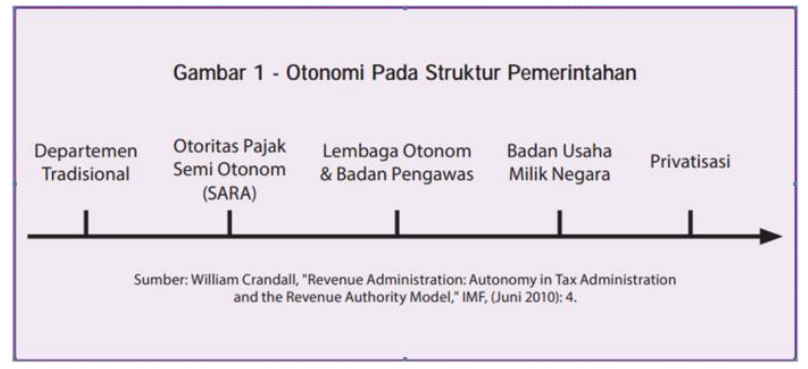

Fig. 1: Autonomy on Government Structure

Source: Crandall, 2010

As described in Fig. 1, tax authorities in various countries are generally located only within the traditional departmental areas (eg France, Cambodia, Indonesia, etc.) and semi-autonomous tax authorities (eg Kenya, Hong Kong, USA, etc.) . There is no single tax authority on characteristics that have greater autonomy than the SARA model, because the power and authority of the tax authorities can not be separated from the control of the elected government. So the tax authority will always be a public institution.

Every model that exists in the government structure of course also already has the authority that has been regulated by the government. It may be that the authority possessed by a particular model in country A differs from country B. This happens because every government in every country must have different conditions and needs. As can be seen in Table 3 on the authority delegated to tax authorities in various countries by 2012.

TABLE III: AUtHoritIES DELEGATED TO TAX AUTHORITIES IN VARIOUS COUNTRIES, 2012

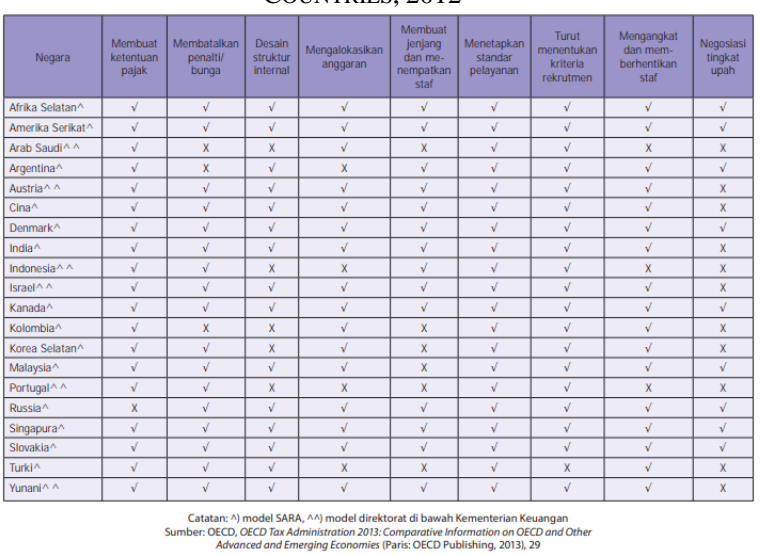

Source: OECD Publishing, 2013

\section{LITERATURE REVIEW}

\section{A. Organizational Theory}

The organization is a consciously coordinated social unit, with a relatively identifiable constraint, working on a relatively continuous basis for achieving common goals[10]. Mintzberg in Sedarmayanti[11] describes the following types of organizational structures:

\section{a. Simple Structure}

The character of this simple structure is uncomplicated, its complexity is low, a bit of formalization and centralized authority.

\section{b. Machine Bureaucracy}

In this model, task standardization is the main characteristic of routines, formalities, rules / procedures, functional departments, concentration of authority, and decision-making to be carried out by subordinates through administrative instructions that distinguish between line functions and staff functions, all of which constitute the central character of the machine bureaucracy.

\section{c. Professional Bureaucracy}

In this model there is a combination of standardization and decentralization.

\section{d. Divisional Structure (Structure on the basis of division of tasks)}

This model is generally known as exemplified in many forms of bureaucratic organization, in which sections are arranged in functional units on the principle of strict division of labor.

\section{e. Adhocracy (Strength for purpose or special case)}

In this model, the role of professional staff stands out, horizontal differentiation is huge, whereas vertical differentiation is very low.

Mintzberg in Sedarmayanti[12] defines the restructuring as follows: 
In terms of organizational structure, structuring means pressing knobs affecting the division of labor and coordination mechanisms, thus affecting how organizational functions, how material processes, authority, information and decisions work in accordance with existing structures

\section{B. Theory of Internal Control Systems}

Widjajanto[13] explains that the principle of organizing an organization in the theory of internal control is: there must be a separation between the functions of recording, implementation, and storage or management; and a function shall not be entirely responsible for carrying out all stages of a transaction from beginning to end.

\section{Theory of Human Resource Management (HRM)}

According to Bangun[14] HRM can be defined as a process of planning, organizing, staffing, mobilization and supervision, on procurement, development, compensation, integration, maintenance and separation of labor to achieve organizational goals.

\section{Theory of the Budget}

The definition of the budget according to Merriam Webster's Collegiate Dictionary in Ratna is as follows:

a. A statement of management financial position in a planned period based on estimated cost and its proposed financing plan during the period.

b. Planning to manage resources and their use.

A sum of money available, needed longer, or intended for a particular purpose.

\section{E. Theory of Information Technology}

Information technology refers to all forms of technology used to create, store, alter, and use information in all its form ${ }^{[15]}$. Public sector organizations are judged to be lagging behind the private sector in the development, implementation and governance of $\mathrm{IT}^{[16]}$.

\section{F. Theory of Tax Administration}

A good institutional framework of taxation administration should, at least, have the following characteristics ${ }^{[17]}$. First, it has financial independence, meaning the new agency / agency can allocate the appropriate budget, which part of the budget can be used for incentive or improvement of information technology. Secondly, the new agency / body is granted autonomous administrative authority and can formulate its policy and administrative objectives. Finally, the new agency / agency must be responsible for managing human resources internally. This can be done through a system of payroll, appointment, training, to formulate its internal code of ethics.

\section{RESEARCH METHODS}

The type of research used is descriptive research with qualitative approach. Descriptive research is a study conducted to test one or more variables without making a comparison or relationship between variables with one another variable[18]. Qualitative research is a study that aims to understand the phenomenon experienced by the subject of research, holistically, and described in the form of words and language, in a specific context that is natural and by utilizing various natural methods[19].

This research is focused on the proper institutional design for DGT for the realization of a good internal control system within the Ministry of Finance. The elements of focus of this research are as follows:

1. Internal control system of the Ministry of Finance

a. Organization system

b. Authority system and recording procedure

c. Implementation of work in a healthy manner

d. Employees with qualities that match the responsibilities

2. DGT Restructuring

a. Design of positions

b. Superstructure design (Design of superstructure)

c. Design of lateral linkage

d. Design of decision making system

The research was conducted at the Ministry of Finance of the Republic of Indonesia and the Head Office of the Directorate Generale of Taxation. Data collection is done by interview and documentation. The steps of data analysis in this study are Miles and Huberman ${ }^{[20]}$ :

1. Data Collection, is an activity to collect data in accordance with the type and nature of the data required.

2. Data Condensation, is the process of selecting, focusing, simplifying, abstraction, and / or changing data found in the field based on field notes, interviews, documents and facts in the field.

3. Data Display, means to organize, compile data or information so as to facilitate the researchers understand the meaning and a data and making it possible for researchers to draw conclusions.

Conclusion Drawing / Verification, in this process data that has been condensed and coupled systematically (in-display) then taken the red thread as a conclusion.

\section{RESEARCH RESULT AND DISCUSSION}

\section{A. Internal Control System of the Ministry of Finance}

\section{a. Organization System}

Based on the Regulation of the Minister of Finance No. 206 / PMK.01 / 2014 on the Organization and Working Procedure of the Ministry of Finance, explains that there is already a clear separation of responsibility established within the Ministry of Finance in the form of organizational structure. The reason for all these functions is in one body in the Ministry of Finance already contained in the State Finance Act which states that all the power of fiscal authority is authorized to the Minister of Finance, the use of which is submitted to other departments. Based on this, the units handling the fiscal management sub-sector remain in the Ministry of Finance.

\section{b. Authority system and recording procedure}

Current conditions illustrate that the DGT has limitations in some powers, including in terms of human resources, organization, budget and information technology. First, in terms of the authority to manage human resources, DGT takes a 
long time to be able to lift or even lay off employees. Second, from the organizational side, such as opening or closing the tax office that requires a very long process. Third and fourth, in terms of budget and information technology. For example, DGT requires a large budget to develop existing information technology as a form of excellent service to the community.

\section{c. Implementation of work in a healthy manner}

Related to this in the Ministry of Finance has been established that is Inspectorate General (Itjen), where the Itjen Ministry of Finance is a Government Internal Supervisory Apparatus (APIP) which has the duty and function of supervising the units within the Ministry of Finance. Supported by the division of supervisory duties for each unit, and coupled with the existing inspection process, this is certainly a separate method in the Ministry of Finance in an effort to ensure the implementation process work in a healthy manner in accordance with the provisions that have been set.

\section{d. Employees with qualities that match the responsibilities}

In relation to the competence of human resources owned by the Ministry of Finance, of course also has been arranged through a unit that is in the structure of the Ministry of Finance, namely the Finance Education and Training Agency (BPPK) of the Ministry of Finance. Certainly needs to be coupled with the existence of a good system, because between the system and HRM this is one thing that can not be separated. Concerns about the existence of moral hazard in existing human resources can certainly be minimized by the existence of a good system in the organization. Likewise a good system will produce positive results when able to run by a good and competent human resources.

\section{B. DGT Restructuring}

\section{a. Design of positions}

Seeing the condition of the current DGT performance certainly feels the need for changes in the DGT body, especially in the context of the authority possessed by the DGT. DGT as a collection agent of state revenue, is certainly part of the state financial management function that is under the responsibility of the Minister of Finance, where the provisions have been regulated in the Law on State Finance. Referring to the law, the idea of establishing the DGT to become a more autonomous body must keep the provisions in place so as not to disturb or deviate from the existing law. So to go to the process made a modification with the status of Government Institutions Non-Ministry (LPNK). LPNK is a state institution in Indonesia established with the aim to perform certain government duties of the President. The position of the Head of LPNK is under and directly responsible to the President through the coordination of the minister concerned.

\section{b. Superstructure design}

Concerning the structural design of the more autonomous tax authorities, as stated in Inside Tax 16th Edition, there are two leadership models in the SARA-based tax authority, the Chief Executive Officer (CEO) model and the Board of Directors
(BOD) model. In the CEO model, the commissioner is usually appointed by the President or the Minister of Finance with a specified term of office. Whereas in the BOD model, the President or Finance Minister will appoint a person to carry out the mandate as head of functioning as executive in SARA, and become part of the board of directors. Referring to the above provisions, then BPP will be chaired by the Head of BPP, then under it there is the Main Secretary of BPP, and will be assisted by deputies where later deputies will oversee the directorate that has been under the DGT and also supervision unit .

\section{c. Design of lateral linkage}

With the realization of the BPP later in the status of LPNK, it is of course necessary to adjust the structure also related to units that will be in contact with BPP such as Taxation Supervisory Commission and BKF. Currently Taxation Supervisory Commission is under the Ministry of Finance because it is also under the DGT Ministry of Finance. Then it can be changed later the function of Taxation Supervisory Commission to assist President through coordination of Minister of Finance. With regards to the affirmation of the tax administrator functions on BPP's body, the tax regulator function will be under the responsibility of the Ministry of Finance's Legal Bureau. In the future implementation, which concerns the amendment of the law will be involved all parties in the bill team, the person responsible is the Legal Bureau of the Ministry of Finance. Only the implementation of the law is BKF, and the operational implementation is handled by the Directorate Generale of Taxation.

\section{d. Design of decision making system}

If it is related to the tax administration, there is no need to involve other parties because it is clearly the authority of BPP itself as a tax administrator. However, if the decision to be taken on public policy should ideally be kept in touch with stakeholders. Furthermore, the tax policy will remain in the Minister of Finance because based on the mandate of the law it is clear that the Minister of Finance as the manager of state finances authorized by the President.

\section{CONCLUSIONS}

\section{A. Internal Control System of the Ministry of Finance}

\section{a. Organization system}

Based on the Law of the Republic of Indonesia Number 17 Year 2003 on State Finance states that the President holds the power of state financial management as part of governmental power. Part of such power is authorized to the Minister of Finance as fiscal manager and government representative in separated state property ownership, as well as to the Minister / Head of Institution as the user of the budget / user of the ministry of the state / institution he leads. This means that all matters relating to fiscal management are the responsibility of the Minister of Finance and in relation to the existing fiscal management sub-sector must be maintained through the separation of units established under the structure of the Ministry of Finance. 


\section{b. Authority system and recording procedure}

Although there are regulations regulating the authority system of each unit within the Ministry of Finance, including the DGT. Apparently over time it is necessary to adjust to the authority possessed by the DGT, considering that must be faced by the DGT is the dynamics of the economy that each time always experience the movement. To be able to deal with it, it is necessary to have the flexibility of authority within the DGT body, especially the authority in terms of human resource management, organization, budget and information technology.

\section{c. Implementation of healthy work}

Based on the authority set forth in the Ministry of Finance, a unit that will perform the supervisory function to ensure the implementation of work can be run in accordance with existing provisions, namely the Inspectorate General (Itjen) of the Ministry of Finance, where the Ministry of Finance is the Government's Internal Supervisory Apparatus (APIP) which has the duty and function of supervising the units within the Ministry of Finance.

\section{d. Employees with qualities that suit the responsibilities}

In relation to the competence of human resources owned by the Ministry of Finance, of course also has been arranged through the existing units within the structure of the Ministry of Finance namely BPPK Ministry of Finance and Tax Training Center. Through the process of quality recruitment and training facilities that support of course this makes the Ministry of Finance and DGT have the quality and competence in the field. The quality of human resources must also be supported by the availability of quantity (addition) of human resources, given the demands to meet the target of increasing the tax ratio, the potential increase in the number of WP, and the importance of service through person to person, and accompanied by a system improvement to minimize the occurrence of things undesirable things.

\section{B. DGT Restructuring}

\section{a. Design of position}

There needs to be a change to make the DGT a more autonomous body, with the record without disturbing the provisions set forth in the State Finance Law by making the DGT a Non-Ministry Government Institution under the name of the Tax Recipient Agency, directly under and accountable to the President through coordination of the Minister of Finance.

\section{b. Superstructure design}

Based on Presidential Decree No. 103/2001, it is mentioned that the organizational structure of LPNK consists of Head, Main Secretary, Deputy, and Supervision Unit. This explains that BPP will structurally be directly under and accountable to the President and conceptually BPP will be chaired by the Head of BPP, then there will be the Main Secretary of BPP, Deputy, and Supervision Unit.

\section{c. Design of lateral linkage}

With the realization of the BPP later in the status of LPNK, under which the structure will be under and accountable to the President, of course Komwas Taxation which originally helped the Minister of Finance can be assigned to assist the President through the coordination of the Minister of Finance. Regarding the tax regulator function will be under the responsibility of Legal Bureau of the Ministry of Finance where it will be involved in all parties in the bill team, then the implementer of the law is BKF, and the operational operators are handled by the Directorate Generale of Taxation.

\section{d. Design of decision making system}

With BPP format later, the design of decision-making that is related to the tax administration certainly does not need to involve other parties because it is clearly already merupkan authority from the BPP itself as a tax administrator. However, if the decision to be discussed on the tax policy will be the responsibility of the Minister of Finance as the manager of the state finances.

\section{ACKNOWLEDGMENT}

First Author would like to thank LPDP Scholarship and Universitas Indonesia for their support. So also the first author would like to thank the Ministry of Finance, the House of Representatives of the Republic of Indonesia, Directorate Generale of Taxation, Danny Darussalam Tax Center and other informants who have helped in completing this research.

\section{REFERENCES}

[1] Bank Dunia. 2015. Laporan Bank Dunia: Pertumbuhan Ekonomi Indonesia Pada 2015 Diperkirakan 5,2 Persen. Available: http://www.worldbank.org/in/news/press-release/2014/12/08/indonesia-t o-grow-by-5-2-percent-in-2015-world-bank-report.

[2] Bank Dunia. 2015. Laporan Bank Dunia: Pertumbuhan Ekonomi Indonesia Pada 2015 Diperkirakan 5,2 Persen. Available: http://www.worldbank.org/in/news/press-release/2014/12/08/indonesia-t o-grow-by-5-2-percent-in-2015-world-bank-report.

[3] Ika. 2014. "Bank Dunia Prediksikan Pertumbuhan Ekonomi Indonesia 2015 Capai 5,2 Persen”. Available: https://ugm.ac.id/id/berita/9598-bank.dunia.prediksikan.pertumbuhan.ek onomi.indonesia.2015.capai.52.persen.

[4] Direktorat Jenderal Pajak. 2014. "Wahyu K. Tumakaka: Otonomi Pajak Adalah Kebutuhan Negara, Bukan DJP yang Ingin 'Merdeka'”. Available:

http://www.pajak.go.id/content/wahju-k-tumakaka-otonomi-pajak-adala h-kebutuhan-negara-bukan-djp-yang-ingin-merdeka.

[5] Direktorat Jenderal Pajak. 2014. "Rizal Djalil, Darussalam, dan Harry Azhar Bicara Tentang Ditjen Pajak". Available: http://www.pajak.go.id/content/rizal-djalil-darussalam-dan-harry-azhar-a zis-bicara-tentang-ditjen-pajak.

[6] Desain Kelembagaan Administrasi Perpajakan: Perlukah Ditjen Pajak Terpisah dari Kementerian Keuangan? Jakarta: DANNY DARUSSALAM Tax Center, 2013.

[7] Desain Kelembagaan Administrasi Perpajakan: Perlukah Ditjen Pajak Terpisah dari Kementerian Keuangan? Jakarta: DANNY DARUSSALAM Tax Center, 2013.

[8] Jenkins, Glenn P. "Modernization of Tax Administrations: Revenue Boards and Privatization as Instruments for Change”. International Tax Program Harvard Institute for International Development, 1994.

[9] Desain Kelembagaan Administrasi Perpajakan: Perlukah Ditjen Pajak Terpisah dari Kementerian Keuangan? Jakarta: DANNY DARUSSALAM Tax Center, 2013.

[10] Robbins, Stephen P. "Teori Organisasi, Struktur, Desain dan Aplikasi". Alih Bahasa: Udaya Jusuf. Edisi 3. Jakarta: Arcan. 1994.

[11] Sedarmayanti. "Restrukturisasi dan Pemberdayaan Organisasi untuk Menghadapi Dinamika Perubahan Lingkungan”. Bandung: CV. Mandar Maju. 2000. 
[12] Sedarmayanti. "Restrukturisasi dan Pemberdayaan Organisasi untuk Menghadapi Dinamika Perubahan Lingkungan". Bandung: CV. Mandar Maju. 2000.

[13] Widjajanto, Nugroho. "Sistem Informasi Akuntansi". Jakarta: Erlanga. 2000.

[14] Bangun, Wilson. "Manajemen Sumber Daya Manusia". Jakarta: Erlangga, 2012.

[15] Suyanto, M. "Pengantar Teknologi Informasi untuk Bisnis". Yogyakarta: Penerbit ANDI. 2005.

[16] Jogiyanto, HM dan Willy Abdillah. "Sistem Tatakelola Teknologi Informasi”. Yogyakarta: ANDI. 2011.

[17] Jenkins, Glenn P. "Modernization of Tax Administrations: Revenue Boards and Privatization as Instruments for Change". International Tax Program Harvard Institute for International Development, 1994.

[18] Sujarweni, V. W. "Metodologi Penelitian". Yogyakarta: PT. Pustaka Baru. 2014.

[19] Moleong, Lexy J. "Metodologi Penelitian Kualitatif". Bandung: PT Remaja Rosdakarya. Halaman 5, Penelitian Kualitatif. 2011.

[20] Miles, Matthew, A. Michael Huberman, and Johnny Saldana "Qualitative Data Analysis: A Methods Sourcebook". SAGE Publications, Inc. 2014.

[21] Crandall, William. "Revenue Administration: Autonomy in Tax Administration and the Revenue Authority Model". IMF Technical Notes and Manuals, 2010.

[22] Organisation for Economic Co-operation and Development. "Tax Administration 2013: Comparative Information on OECD and Other Advanced and Emerging Economies" (Paris: OECD Publishing, 2013), 25, 2013.

[23] Nurhayat, Wiji. 2014. "Dirjen Pajak: Sudah 12 Tahun Target Pajak Tak Pernah Tercapai". Available: http://finance.detik.com/read/2014/09/09/182828/2685701/4/dirjen-paja k-sudah-12-tahun-target-pajak-tak-pernah-tercapai.

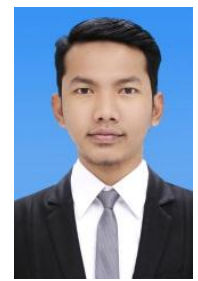

First Author was born in a small village in West Sumatera (Indonesia) named Sitapung on August 11, 1993. He is currently studying master's Administration and Tax Policy at the Universitas Indonesia. And previously has obtained a Bachelor of Taxation (S. Pn.) at the Universitas Brawijaya (Malang, Indonesia) in 2015.

During the study period he is active in organizational activities, ranging form Student Executive Board, Campus Da'wah Organization, Study Program Students Association and others. Before earning a bachelor's degree, he also had an internship at a Public Accounting Firm in Malang in Tax Division. Then after graduation, he decided to enroll for the selection of LPDP Scholarship to continue his master's studies, then escaped and continued his master's studies at the Universitas Indonesia.

Mr. Andiko, ever get the best graduate degree from Universitas Brawijaya thanks to the achievement of GPA of 3.66. 